\title{
Mass Spectrometry in Earth Sciences: The Precise and Accurate Measurement of Time
}

\author{
Urs Schaltegger ${ }^{\star}$, Jörn-Frederik Wotzlaw, Maria Ovtcharova, Massimo Chiaradia, \\ and Richard Spikings
}

\begin{abstract}
Precise determinations of the isotopic compositions of a variety of elements is a widely applied tool in Earth sciences. Isotope ratios are used to quantify rates of geological processes that occurred during the previous 4.5 billion years, and also at the present time. An outstanding application is geochronology, which utilizes the production of radiogenic daughter isotopes by the radioactive decay of parent isotopes. Geochronological tools, involving isotopic analysis of selected elements from smallest volumes of minerals by thermal ionization mass spectrometry, provide precise and accurate measurements of time throughout the geological history of our planet over nine orders of magnitude, from the accretion of the proto-planetary disk, to the timing of the last glaciation. This article summarizes the recent efforts of the Isotope Geochemistry, Geochronology and Thermochronology research group at the University of Geneva to advance the U-Pb geochronological tool to achieve unprecedented precision and accuracy, and presents two examples of its application to two significant open questions in Earth sciences: what are the triggers and timescales of volcanic supereruptions, and what were the causes of mass extinctions in the geological past, driven by global climatic and environmental deterioration?
\end{abstract}

Keywords: Age determination · Mass extinctions · Supervolcanoes · Thermal ionization mass spectrometry · $\mathrm{U}-\mathrm{Pb} \cdot$ Zircon

\section{The Foundation of Geochronology}

The analysis of time in the geological past is called geochronology. A plethora of geological proxies have been developed over the last 300 years to quantify Earth time, including measuring the salinity of the oceans, or the thickness of geological rock strata. Arthur Holmes ${ }^{[1]}$ was the first to state that the accumulation of lead in uranium-rich minerals would be the most reliable way of determining an age of a rock, even without knowing about the existence of the different isotopes of uranium. The secular equilibrium decay chain of ${ }^{238} \mathrm{U}$ to ${ }^{206} \mathrm{~Pb}$ generates eight alpha particles, with a half-life of $4.468 \mathrm{Ga}$ (Fig. 1, top). The second decay chain from ${ }^{235} \mathrm{U}$ to ${ }^{207} \mathrm{~Pb}$ (half-life of $704 \mathrm{Ma}$ ) provides insufficient precision for rocks younger than approximately 300 million years (Ma) due to quasi-extinction of the parent after more than five half-lives. Both of these decay chains represent natural clocks, and the essential information required to read the

${ }^{*}$ Correspondence: Prof. Dr. U. Schaltegger University of Geneva

Section of Earth and Environmental Sciences

Rue des Maraîchers 13

$\mathrm{CH}-1205$ Geneva

Tel. +412237966 38

E-mail address: urs.schaltegger@unige.ch time is i) measurement of the abundances of the parent and daughter isotopes, and ii) experimental determination of the decay constant, which is the rate at which the parent $\left({ }^{238} \mathrm{U},{ }^{235} \mathrm{U}\right)$ decays into the daughter $\left({ }^{206} \mathrm{~Pb},{ }^{207} \mathrm{~Pb}\right)$.

Radioactive-parent/radiogenic-daughter couples therefore offer the possibility of age determination, relying on wellknown constants for the rate of radioactive decay and on the isotopic composition of the elements in question, e.g. the ${ }^{40} \mathrm{~K} /{ }^{40} \mathrm{Ar}$, ${ }^{87} \mathrm{Rb} /{ }^{87} \mathrm{Sr},{ }^{147} \mathrm{Sm} /{ }^{143} \mathrm{Nd}$, or ${ }^{187} \mathrm{Re} / 187 \mathrm{Os}$ couples.

\section{High-precision U-Pb Geochronology}

The U-Pb parent/daughter radioactive couple may be used for dating any mineral phase that has a sufficiently high parent isotope concentration, and a high parent/daughter ratio incorporated into the mineral lattice during its crystallization. Among the most used minerals are silicates (zircon $\mathrm{ZrSiO}_{4}$; titanite, synonymous to sphene, $\mathrm{CaTiSiO}_{5}$ ), oxides (baddeleyite $\mathrm{ZrO}_{2}$; rutile $\mathrm{TiO}_{2}$ ) and phosphates (monazite [La, Ce]PO $\mathrm{PO}_{4}$; xenotime $\mathrm{YPO}_{4}$ ). In the following we restrict the discussion to the mineral zircon, which is the most suitable candidate for high-precision $\mathrm{U}-\mathrm{Pb}$ geochronology because of its high chemical and mechanical resistivity, leading to

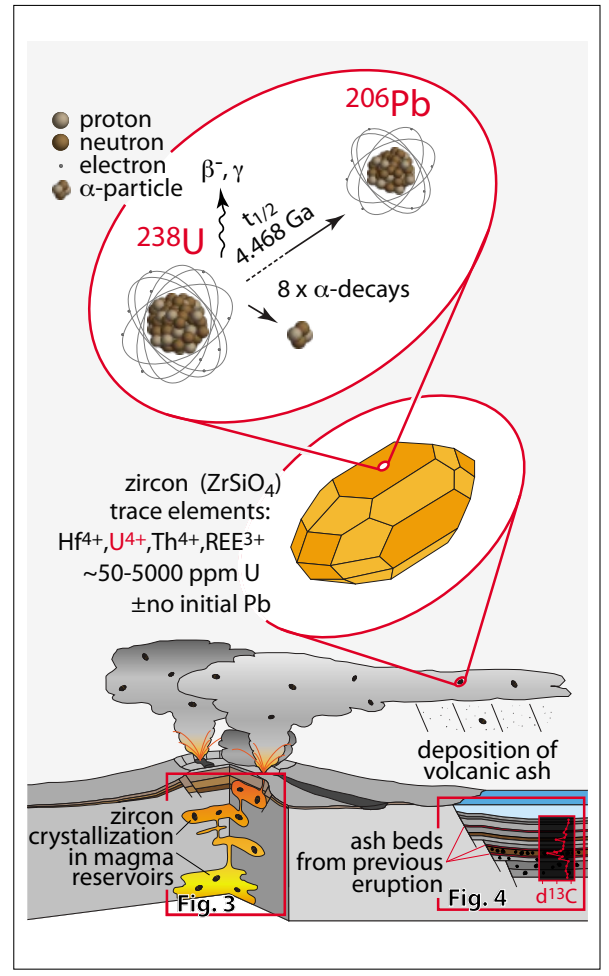

Fig. 1. Principles and applications of zircon $\mathrm{U}-\mathrm{Pb}$ geochronology. The alpha decay chain from ${ }^{238} \mathrm{U}$ to ${ }^{206} \mathrm{~Pb}$ is used to obtain numerical age information from $U$-bearing zircon. These techniques are used for detailed reconstruction of magma reservoir evolution in volcanic systems, and for numerical calibration of sedimentary sequences for the study of biodiversity changes in the geological past (mass extinctions). 
very refractory behaviour during thermal or fluid-induced overprinting of rocks, as well as during sedimentary transport in debris flows or fluvial systems.

The zircon lattice is known to provide stoichiometric sites that can accommodate $5^{+}$ions (e.g. P, on the 4-fold coordinated Si site), $4^{+}$ions ( $\mathrm{U}, \mathrm{Th}$, Hf replacing the $\mathrm{Zr}$ site in 6-fold coordination), and $3^{+}$ions (lanthanides/rare earth elements, Y, also replacing the $\mathrm{Zr}$ site), see Fig. 1, middle. On the contrary, divalent cations can only be accommodated in interstitial sites (e.g. $\left.\mathrm{Pb}^{2+}, \mathrm{Fe}^{2+}, \mathrm{Mo}^{2+}\right)$. These elemental substitutions can be expressed in terms of solid solutions between different mineral end members, among them thorite $\left(\mathrm{ThSiO}_{4}\right.$; $\mathrm{ZrTh}_{-1}$ exchange), coffinite $\left(\mathrm{USiO}_{4} ; \mathrm{ZrU}_{-1}\right)$, hafnon $\left(\mathrm{HfSiO}_{4} ; \mathrm{ZrHf}_{-1}\right)$, and xenotime $\left(\mathrm{YPO}_{4} ; \mathrm{ZrSiY}_{-1} \mathrm{P}_{-1}\right)$. The zircon chemical system therefore efficiently excludes the daughter element $\mathrm{Pb}$, and thus offers high to very high initial $\mathrm{U} / \mathrm{Pb}$ ratios, enabling direct calculation of ${ }^{206} \mathrm{~Pb} /{ }^{238} \mathrm{U}$ and ${ }^{207} \mathrm{~Pb} /{ }^{235} \mathrm{U}$ ages after subtraction of a minor initial $\mathrm{Pb}$ component. The high stability of the zircon lattice gives rise to some of the lowest known diffusivities of the elements in question through the zircon lattice (see experimental studies by Cherniak et $\left.a l .{ }^{[2,3]}\right)$. However, the crystal lattice of zircon can be damaged by alpha particles that are liberated during the radioactive decay of ${ }^{238} \mathrm{U},{ }^{235} \mathrm{U},{ }^{232} \mathrm{Th}$ and ${ }^{147} \mathrm{Sm}$, eventually resulting in a metamict structure. ${ }^{[4]}$ Ions can diffuse easily in metamict zircon at low temperatures, leading to partial open system behaviour and the partial loss of the radiogenic daughter, especially in the presence of circulating aqueous solutions.

$\mathrm{U}-\mathrm{Pb}$ age determinations can be carried out by techniques that provide spatial resolution within a single mineral grain, using either a primary ion beam that sputters the target ions from the mineral surface and separates the ions in a large-radius, sector-field mass spectrometer (secondary ion mass spectrometer, SIMS), or by laser ablation and subsequent ionization by an inductively coupled plasma source and ion detection in a sector-field or quadrupole mass spectrometer (LA-ICPMS; Fig. 2A). The small volume of analyzed material (tens of $\mu \mathrm{m}^{3}$ in the case of SIMS; hundreds of $\mu \mathrm{m}^{3}$ for LA-ICP-MS) translates to an analytical uncertainty on a single spot ${ }^{206} \mathrm{~Pb}^{238} \mathrm{U}$ date of $2-4 \%$. If we pool together more than 10 analyses from volcanic zircon (e.g. extracted from airborne ash beds), we may get a best estimation of an age of $250 \pm 2.5 \mathrm{Ma}$, using the PermianTriassic boundary as an example (all dates at $2 \sigma$ uncertainty level; Fig. $2 B$ ).

If we wish to determine the age of the boundary with the highest possible precision and accuracy, then the Chemical Abrasion-Isotope Dilution-Thermal Ion- ization Mass Spectrometry (CA-ID-TIMS) technique must be used. This technique first removes alpha decay-damaged portions of the crystal by thermal annealing and subsequent partial dissolution, a technique developed by Mattinson. ${ }^{[5]}$ High precision and accuracy are achieved by adding a well-calibrated double-isotope tracer solution ${ }^{202} \mathrm{~Pb}-{ }^{205} \mathrm{~Pb},{ }^{233} \mathrm{U}-{ }^{235} \mathrm{U}$; www.earthtime.org) to the sample (isotope dilution) to precisely and accurately determine the isotope compositions and parent/daughter ratios, and also directly correct for instrument-induced isotope fractionation during analysis. The target elements are then isolated by chromatographic techniques in an ultra-clean environment and their isotopic compositions are analyzed using a thermal ionization mass spectrometer, equipped with a highly linear ion counting system. The resulting precision from one single crystal or a fragment of a crystal is usually better than $\pm 0.2 \%$, equal to \pm 0.5 Ma for an age of $250 \mathrm{Ma}$, or $\pm 0.02 \%$ when pooling ten statistically equivalent analyses into a weighted mean, equal to $\pm 0.05 \mathrm{Ma}$ (Fig. $2 \mathrm{~B})$. We may have an interest in imaging

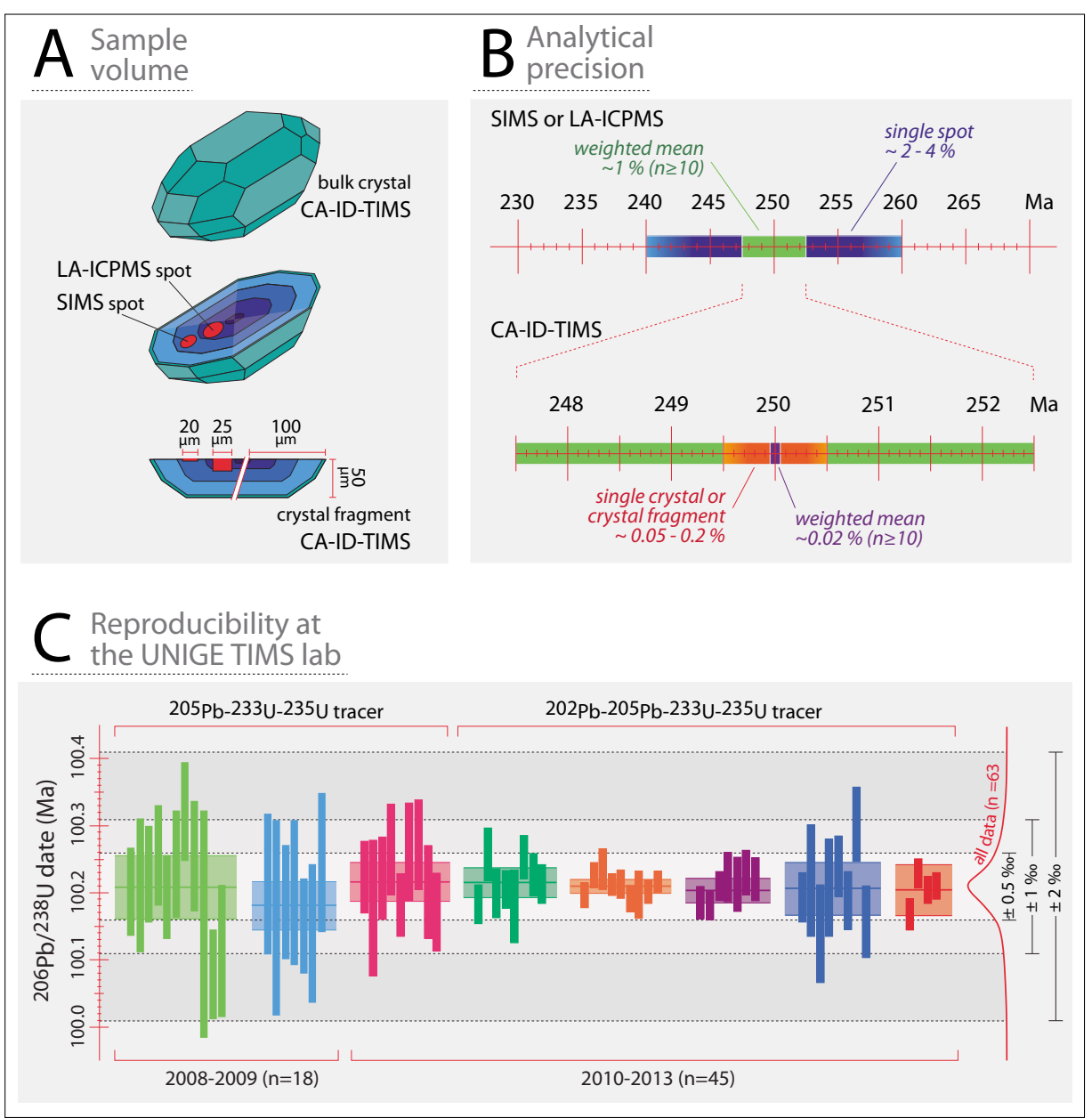

Fig. 2. Analytical techniques of high-precision U-Pb geochronology. CA-ID-TIMS: chemical-abrasion, isotope-dilution thermal ionization mass spectrometry; SIMS: secondary ion mass spectrometry; LA-ICP-MS: laser ablation inductively coupled plasma mass spectrometry. A: analyzed sample volumes for different techniques of $\mathrm{U}-\mathrm{Pb}$ geochronology; $\mathrm{B}$ : comparison of analytical uncertainties, all values given at the $2 \sigma$ level; C: reproducibility of a synthetic standard solution in the isotope laboratory at University of Geneva. the internal growth textures in an equatorial section of a zircon using its cathodoluminescence, or by using back-scattered electrons, prior to $\mathrm{U}-\mathrm{Pb}$ analysis (Fig. 2A).

Recent methodological developments ibrated isotopic tracer solutions and applying refined calibration procedures have pushed the $\mathrm{U}-\mathrm{Pb}$ dating technique towards unprecedented precision and accuracy (see recent review by Schoene ${ }^{[6]}$ ), which requires continuous control on the different procedural parameters that introduce random and systematic errors. Our precision and long-term reproducibility is controlled by continuous measurement of a synthetic solution mimicking an approximately 100 Ma-old zircon, ideally analyzed in sessions containing ten measurements for the quantification of short-term variations, and compared over the last five years (Fig. 2C). The data demonstrate that we achieve a long-term reproducibility of better than $\pm 0.05 \%$ on the ${ }^{206} \mathrm{~Pb}^{238} \mathrm{U}$ date. This uncertainty includes the use of two different tracer solutions (implying a different procedure for source fractionation correction such as world-wide sharing of well-cal- 
during analysis), and different Secondary Electron Multipliers on the mass spectrometers. The accuracy of our whole procedure is controlled by continuous measurement of natural zircon standards, which have been analyzed in different laboratories (e.g. Slama et al. $\left.{ }^{[7]}\right)$. To achieve the reproducibility shown in Fig. 2C, a series of error sources have to be minimized, quantified and correctly propagated into the final uncertainty: i) highest possible radiogenic/ common $\mathrm{Pb}$ ratios, related to lowest possible procedural contamination blanks (currently $3 \times 10^{-13}$ g per analysis); ii) accurate isotopic ratio applied to the correction for any non-radiogenic $\mathrm{Pb}$; iii) accurate correction of initial ${ }^{230} \mathrm{Th}$ and ${ }^{231} \mathrm{~Pa}$ disequilibrium leading to unsupported ${ }^{206} \mathrm{~Pb}$ and ${ }^{207} \mathrm{~Pb}$, respectively.

The above-described techniques applied to a large variety of geochronological problems where the rates of processes need to be precisely and accurately known, such as metal transport in melts and fluids and their precipitation to form ore deposits, or the response of rock uplift, erosion, topography and climate to plate tectonics. On a universal to planetary scale, the methods discussed above allow, for example, quantification of time during condensation of the earliest materials after nucleosynthesis, which are preserved within calciumaluminium inclusions in carbonaceous chondrites. ${ }^{[8]}$

We present two examples showing how high-precision U-Pb geochronology improves our understanding of geological processes by quantifying their durations and rates, with a very high precision.

\section{Supervolcanoes}

The most voluminous silicic supereruptions in Earth history were associated with the collapse of calderas above giant silicic magma reservoirs (Fig. 3). Prominent examples are the caldera-forming eruptions of the Yellowstone ${ }^{[9]}$ and Toba supervolcanos, ${ }^{[10]}$ and the eruptions of the Bishop Tuff ${ }^{[11]}$ and Fish Canyon. ${ }^{[12]}$ With a total volume of about $5000 \mathrm{~km}^{3}$, the $28.2 \mathrm{mil}-$ lion years (Ma) old Fish Canyon Tuff represents the eruptive product of the most voluminous supereruption known from the geologic record. Using a combination of high-precision $\mathrm{U}-\mathrm{Pb}$ dating ${ }^{[12]}$ and trace element analysis of the same zircon crystals, developed by Schoene et al., ${ }^{[13]}$ the pre-eruption evolution of the Fish Canyon magmatic system was reconstructed. [12] The series of graphics and diagrams in Fig. 3 depicts the evolution of the giant eruption feeding magmatic system, as recorded by the crystallization ages and trace element compositions of zircons. Initially, a magma chamber was established below the dormant caldera at 28.6 Ma (Fig. 3A). The initial crystal content of the magma was sufficiently low (20-40 vol. \% crystals suspended in a highly viscous rhyolitic liquid) to allow convective homogenization of the entire volume, or in sub-volumes, represented by the crystallization of zircon with identical Yb/Dy ratios, over approximately 150 '000 years. A period of overall cooling of the magmatic system between 28.5 and 28.4 Ma led to an increase of the crystal fraction through the growth of minerals including plagioclase, quartz and sanidine, resulting in almost complete solidification of the magma. Co-crystallization of titanite (characterized by low Yb/Dy, medium [Yb], and high [Dy]) led to a differential depletion of the middle and heavy rare earth

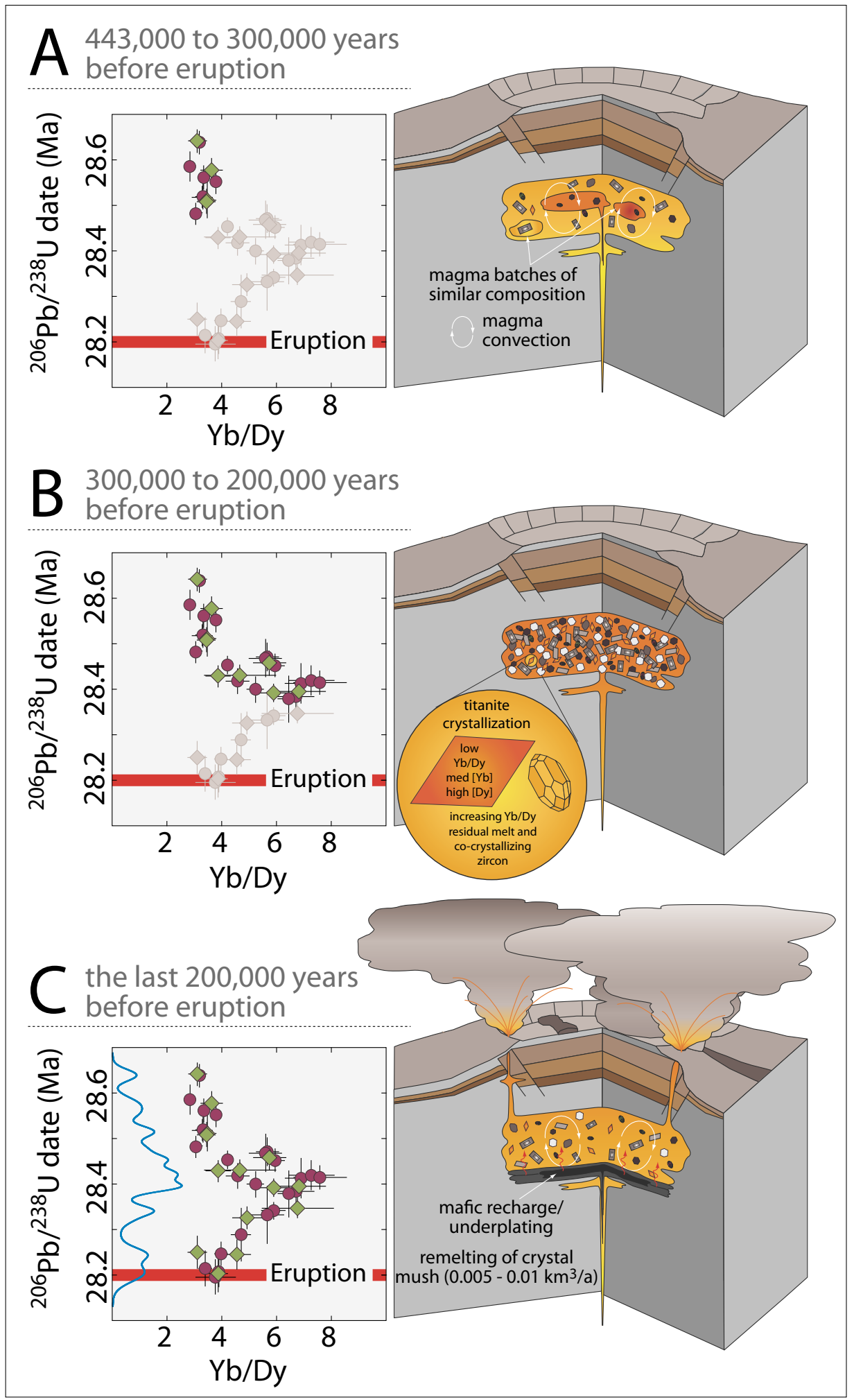

Fig. 3. Reconstruction of the crystallization history of a giant silicic magma reservoir during its 600 '000 year-long residence in the upper crust, ending with the supereruption of the 28.19 Ma old Fish Canyon Tuff, western USA (redrawn from Wotzlaw et al. ${ }^{[12]}$ ). 
elements in the residual liquid, reflected by increasing $\mathrm{Yb} / \mathrm{Dy}$ ratios of co-precipitating zircons (Fig. 3B). During the last 200'000 years before eruption, recharge of the magmatic system by $200-300{ }^{\circ} \mathrm{C}$ hotter, volatile-saturated andesitic magma led to re-melting of the crystal mush at rates of 0.005 to $0.01 \mathrm{~km}^{3} / \mathrm{a}$, reducing the content of crystals to approximately 45 vol. $\%$. The resulting overpressure of the magmatic system lead to the explosive eruption and concomitant caldera collapse.

This example shows that we are able not only to temporally resolve the history of crystallization and chemical fractionation in a magmatic system, but also infer fluctuations in temperature, chemical composition and crystal content in the stagnant melt. Using these data, we can model the magma flux over the lifetime of the magmatic system as well as the rheological nature of the involved melts, and consequently bracket the boundary conditions for a giant magmatic system to produce a supereruption.

The age of eruption may also be determined by applying the ${ }^{40} \mathrm{Ar}-{ }^{39} \mathrm{Ar}$ technique to the mineral sanidine, which is the volcanic polymorph of alkaline feldspar $[(\mathrm{K}, \mathrm{Na})$ $\left.(\mathrm{Al}, \mathrm{Si}){ }_{4} \mathrm{O}_{8}\right]$. The ${ }^{40} \mathrm{Ar}-{ }^{39} \mathrm{Ar}$ technique is based on the radioactive decay of ${ }^{40} \mathrm{~K}$ to ${ }^{40} \mathrm{Ar}$, although our inaccurate knowledge of the ${ }^{40} \mathrm{~K}$ decay and other physical constants, such as the ${ }^{40} \mathrm{Ar} /{ }^{40} \mathrm{Ca}$ branching ratio and the natural ${ }^{40} \mathrm{~K} / \mathrm{K}_{\text {tot }}$ ratio, leads to a systematic, $-0.8 \%$ offset of ${ }^{40} \mathrm{Ar}^{39} \mathrm{Ar}$ dates compared to ${ }^{206} \mathrm{~Pb}^{238} \mathrm{U}$ dates. ${ }^{[14,15]}$ This inconsistency, paired with a method-inherent lower analytical precision compared to $\mathrm{U}-\mathrm{Pb}$, renders direct comparison of $\mathrm{U}-\mathrm{Pb}$ and ${ }^{40} \mathrm{Ar}-{ }^{39} \mathrm{Ar}$ dates problematic at the present time.

\section{Mass Extinctions - Causes and Effects}

Important geological boundaries are usually characterized by drastic changes in biotic assemblages and drops in paleobiodiversity of fossil fauna and/or flora. Such events, colloquially called 'mass extinctions', have been put into the context of an impact of an extra-terrestrial bolide onto our planet, ${ }^{[16]}$ triggering the end-Cretaceous mass extinction 65 million years ago. However, the temporal coincidence between mass extinctions and huge basaltic volcanic eruptions in Large Igneous Provinces (LIPs) serves as an argument for linking climatic and environmental overturns on a global scale with the injection of large volumes of gases $\left(\mathrm{CO}_{2}, \mathrm{CH}_{4}, \mathrm{SO}_{2}\right)$ into the stratosphere. ${ }^{[17]}$ These gases are either directly exsolved from decompressing magma during ascent into the upper crust and extrusion onto the terrestrial surface, or may be derived from thermal metamorphism of organic-rich sedimentary cover rocks from hot $\left(>1000^{\circ} \mathrm{C}\right)$ mantle magma. High-precision geochronology is applicable for investigating the temporal relationships between magmatism, chemical proxies for change in temperature (oxygen isotopes) or paleoproductivity (carbon isotopes), and biotic response (change in biodiversity, i.e. taxonomic richness), and their coincidence is a logical argument for a causal relationship. To achieve this, well-selected sedimentary successions are calibrated by high-precision U-Pb geochronology using zircon from interbedded volcanic ash beds.

Volcanic eruptions of LIPs are mainly composed of mafic lithologies; the search for andesitic to basaltic members that saturated during crystallization with respect to zircon $\left(\mathrm{ZrSiO}_{4}\right)$ or baddeleyite $\left(\mathrm{ZrO}_{2}\right)$ remains a great challenge.

\section{The Mass Extinction at the Triassic-Jurassic boundary (TJB)}

The Triassic-Jurassic boundary (TJB) represents one of the most important biotic crises in Earth history, resulting in the disappearance of approximately $80 \%$ of all known species on land and in the sea. Fig. 4 describes how high-precision $\mathrm{U}-\mathrm{Pb}$ age determinations may be used to establish precise temporal coincidence, and thus draw conclusions about causality. Widespread magmatic activity of the Central Atlantic Magmatic Province (CAMP) during the disassembly of Pangaea, and the separation of European, African and North American plates, may have been the trigger for this catastrophic biotic event (e.g. Marzoli et al.,[18] Whiteside et al. ${ }^{[19]}$ ), and also resulted in large basalt flows in the Newark Basin in eastern US and in the Fundy Basin in Nova Scotia, Canada (1 in Fig. 4).

To establish the temporal coincidence of CAMP volcanism with the massive deterioration of environment and reduction of biodiversity, accurate and precise age determinations from both a marine and perfectly calibrated sedimentary section across the TJB, as well as of volcanic rocks, are required. A high-precision geochronologic calibration of both the sedimentary as well as the volcanic record is the only strategy to overcome disparate chronologies resulting from imperfect, imprecise or even erroneous magneto-, cyclo-, and biostratigraphic calibrations. On the basis of the existing ${ }^{40} \mathrm{Ar}^{39} \mathrm{Ar}$ database, the duration of CAMP activity was estimated to be less than 500'000 years, i.e. within the uncertainty of this dating technique. The requirement for a temporal resolution of this duration is therefore a precision at better than \pm 250 ' 000 years for a ${ }^{206} \mathrm{~Pb} /{ }^{238} \mathrm{U}$ date, i.e. at around $0.1 \%(2 \sigma)$ for an approximate age of $200 \mathrm{Ma}$, which can be achieved using the CA-ID-TIMS dating technique (Fig. 2B).

A perfectly suitable sedimentary succession spanning the uppermost Triassic to lower Jurassic was studied in the Pucara Basin of northern Peru (2 in Fig. 4), which yielded a precise determination of the 4.15 $\pm 0.43 \mathrm{Ma}$ long duration of the marine Rhaetian stage (latest Triassic) and its pre-

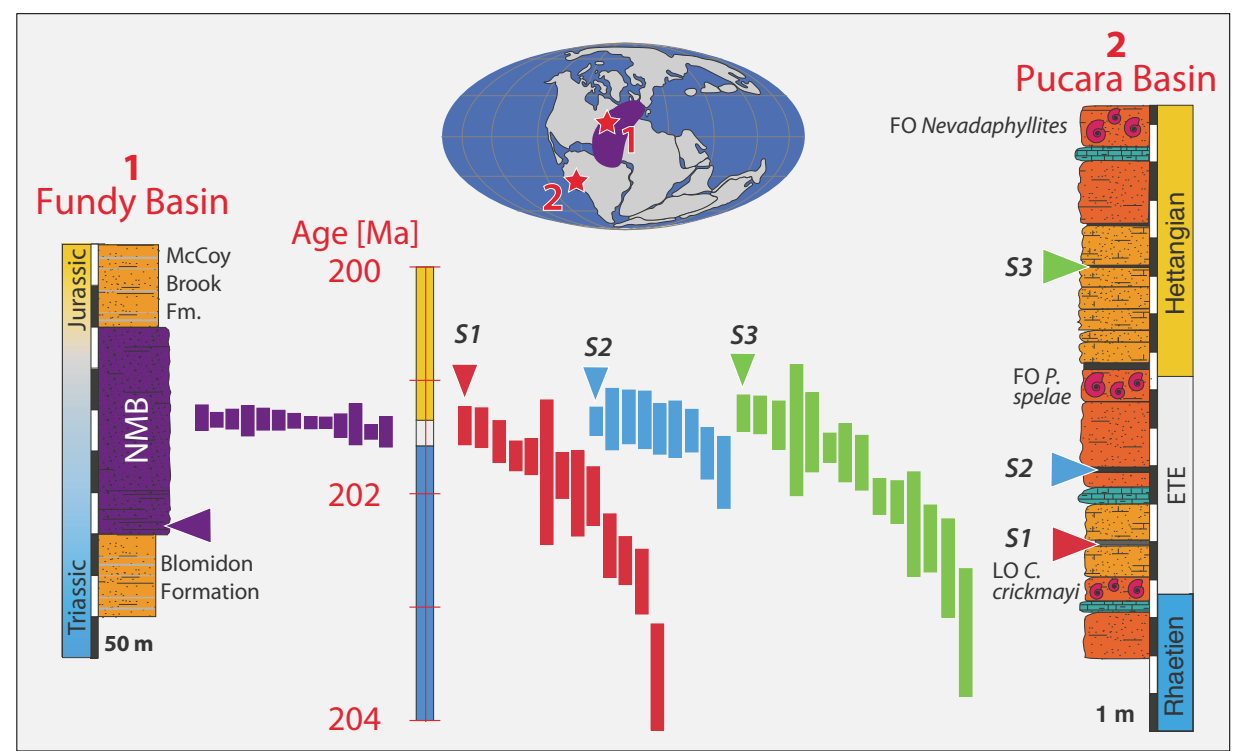

Fig. 4. Using precise temporal coincidence between basaltic eruption of the North Mountain Basalt (NMB), the lowest and oldest lava flow of the Central Atlantic Magmatic Province (CAMP) in eastern Canada, and the mass extinction at the Triassic-Jurassic boundary, monitored in a sedimentary section in the Pucara Basin, Peru. Zircon from three volcanic ash samples (S1, S2, S3) show excess age dispersion beyond analytical scatter due to pre-eruptive residence in the magmatic system; the youngest dates are considered as closest approximation of the age of ash deposition. Modified from Schoene et al. ${ }^{[20]}$ 
extinction fauna. Zircon dates from three volcanic ash beds S1, S2 and S3 precisely and accurately bracket the first occurrence of the ammonite Psiloceras spelae, an internationally agreed marker for the onset of the Triassic stage, at $201.36 \pm 0.17$ Ma. ${ }^{[20-22]}$ The zircon ${ }^{206} \mathrm{~Pb} /{ }^{238} \mathrm{U}$ dates span a range of over $2 \mathrm{Ma}$, which is explained by recycling of zircon from earlier crystallization stages in the magmatic system, as shown in Fig. 3. The youngest date of the population of CA-ID-TIMS dates in any given sample is considered to be closest to the eruption and ash deposition age. The post-extinction biotic recovery has been studied in detail using ammonoid faunas and is restricted to the Hettangian (earliest Jurassic stage), ending at $199.53 \pm 0.19$ Ma.[23]

The temporal coincidence is established by a high-precision $\mathrm{U}-\mathrm{Pb}$ date on the North Mountain Basalt (NTB), the lowest basalt flow of the CAMP in the Bay of Fundy area, yielding an age of 201.481 $\pm 0.021 \mathrm{Ma} .{ }^{[20,22]}$ This latter age has been non-perfectly matched by the age determinations of Blackburn et al. ${ }^{[24]}$ at $201.566 \pm$ $0.031 \mathrm{Ma}$, demonstrating the existence of residual analytical interlaboratory biases at this highest precision. A close temporal coincidence (established on one single sample!) serves as the major argument for volcanism of the CAMP being responsible for massive $\mathrm{CO}_{2}$ injection into the atmosphere, and a subsequent temperature increase, oceanic anoxia and the associated drastic reduction of paleo-biodiversity (mass extinction).

\section{Future Research Directions}

Which are the scientific topics that may require further refinement of our analytical techniques or further development of our geological concepts? Temporal coincidence between volcanism and mass extinctions has to be reproducibly demon- strated and is not a completely satisfactory argument for causality. Feedback rates of bioproductivity and biodiversity to atmospheric greenhouse gas loading and global warming lead to response times that are several orders of magnitude smaller than our best analytical precision. Since most of the feedback mechanisms do not leave direct traces in the geological record, we have to develop a better understanding of the chemical proxies we use. On the analytical side, developing higher analytical precision for isotope analysis of picogram quantities of $\mathrm{Pb}$ could be achieved by replacing secondary electron multiplier or photomultiplier based ion counting ${ }^{[25]}$ by ion detection using Tera-ohm resistivity faraday cups, ${ }^{[26]}$ or by increasing ion yields from thermal ionization through development of new catalyzer substances. Higher precision is, however, often counterbalanced by compromised internal and external analytical reproducibility. These issues are addressed by an intense international collaboration between the specialized laboratories in the frame of EARTHTIME (see www.earth-time.org). A major limit is imposed because we are analyzing natural materials for high-precision geochronology, which demands full control on the system-inherent complexities, such as partial loss of radiogenic daughter product throughout the geological history, initial isotopic disequilibrium of ${ }^{230} \mathrm{Th}$ and ${ }^{231} \mathrm{~Pa}$ during the crystallization of zircon, or protracted residence of zircon crystals in a magmatic liquid prior to its volcanic eruption and deposition from an airborne ash.

\section{Acknowledgements}

The Swiss National Foundation for Scientific research is gratefully acknowledged for continuous funding of research carried out in the Isotope laboratories at the University of Geneva.

Received: February 8, 2014
[1] A. Holmes, Proc. Roy. Soc. London 1911, 85A, 248.

[2] D. J. Cherniak, E. B. Watson, Chem. Geol. 2001, 172, 5 .

[3] D. J. Cherniak, E. B. Watson, Rev. Min. Geochem. 2003, 53, 113.

[4] T. Murakami, Am. Mineral. 1999, 1.

[5] J. Mattinson, Chem. Geol. 2005, 220, 47.

[6] B. Schoene, 'Treatise of Geochemistry, The Crust', 2nd ed., Elsevier, 2014.

[7] J. Sláma, J. Košler, D. J. Condon, J. L. Crowley, A. Gerdes, J. M. Hanchar, M. S. A. Horstwood, G. A. Morris, L. Nasdala, N. Norberg, U. Schaltegger, B. Schoene, M. N. Tubrett, M. J. Whitehouse, Chem. Geol. 2008, 249, 1.

[8] Y. Amelin, A. Kaltenbach, T. Iizuka, C. H. Stirling, T. R. Ireland, M. Petaev, S. B. Jacobsen, Earth Planet. Sci. Lett. 2010, 300, 343.

[9] I. N. Bindeman, J. W. Valley, J. L. Wooden, H. M. Persing, Earth Planet. Sci. Lett. 2001, 189, 197.

[10] J. Vazquez, M. Reid, Science 2004, 305, 991.

[11] J. Crowley, B. Schoene, S. Bowring, Geology 2007, 35, 1123.

[12] J. F. Wotzlaw, U. Schaltegger, D. A. Frick, M. A. Dungan, A. Gerdes, D. Günther, Geology 2013, $41,867$.

[13] B. Schoene, C. Latkoczy, U. Schaltegger, D. Günther, Geochim. Cosmochim. Acta 2010, 74, 7144.

[14] K. Min, R. Mundil, P. R. Renne, K. R. Ludwig, Geochim. Cosmochim. Acta 2000, 64, 73.

[15] P. R. Renne, R. Mundil, G. Balco, K. Min, K. R. Ludwig, Geochim. Cosmochim. Acta 2010, 74, 5349.

[16] L. W. Alvarez, W. Alvarez, F. Asaro, H. V. Michel, Science 1980, 208, 1095.

[17] V. Courtillot, P. Renne, C. R.-Géosci. 2003, $335,113$.

[18] A. Marzoli, H. Bertrand, K. Knight, S. Cirilli, N. Buratti, C. Verati, S. Nomade, P. Renne, N. Youbi, R. Martini, Geology 2004, 32, 973.

[19] J. Whiteside, P. Olsen, D. Kent, S. Fowell, M. Et-Touhami, Palaeogeogr., Palaeoclim., Palaeoecol. 2007, 244, 345.

[20] B. Schoene, J. Guex, A. Bartolini, U. Schaltegger, T. J. Blackburn, Geology 2010, 38, 387.

[21] J. Guex, B. Schoene, A. Bartolini, J. Spangenberg, U. Schaltegger, L. O'Dogherty, D. Taylor, H. Bucher, V. Atudorei, Palaeogeogr., Palaeoclim., Palaeoecol. 2012, 346, 1.

[22] J. F. Wotzlaw, A. Bartolini, J. Guex, Y. Gallet, L. Krystyn, C. McRoberts, D. Taylor, B. Schoene, U. Schaltegger, Geology, in revision.

[23] U. Schaltegger, J. Guex, A. Bartolini, B. Schoene, M. Ovtcharova, Earth Planet. Sci. Lett. 2008, 267, 266.

[24] T. J. Blackburn, S. A. Bowring, J. T. Perron, K. H. Mahan, F. O. Dudas, K. R. Barnhart, Science 2012, 335, 73 .

[25] S. Richter, S. Goldberg, P. Mason, A. Traina, J. Schwieters, Int. J. Mass Spectrom. 2001, 206, 105.

[26] J. M. Koornneef, C. Bouman, J. B. Schwieters, G. R. Davies, J. Anal. Atom. Spectrom. 2013, 28,749 . 